\title{
PHONETIC INTERFERENCE - AS A RESULT OF THE INTERACTION OF LANGUAGES
}

\author{
Kamala Salixovna Kodirova
}

Doctor Of Philosophy (Phd) In Pedagogics, Uzbek State World Languages University, Uzbekistan

\section{ABSTRACT}

This article examines a modern model of teaching Arabic pronunciation in the Uzbek audience, which provides for a theoretical substantiation of the methodological postulate and the development of an effective technology for the formation of auditory-pronunciation skills, namely, for the first time, a comparative typological study of the entire consonant composition of the Arabic and Uzbek languages is carried out, as well as proposed a set of exercises that helps to overcome phonetic interference when teaching Arabic in an Uzbek audience and guidelines for teachers and students.

The modern period of development of independent Uzbekistan dictates the need to develop a methodology for teaching the Arabic language in the Uzbek audience.

KEYWORDS: - Interference, consonantism, phonetics, phonology, exercises, classification, pronunciation, technique.

\section{INTRODUCTION}

When organizing the educational process, the achievements of modern sciences should be applied in each lesson. At the same time, the teacher is obliged to possess modern knowledge and skills, especially in the field of psychology, psycholinguistics and pedagogy. Moreover, classes should be organized according to the principle of consistency, since only a scientifically grounded, methodically thought out and detailed learning process can give positive results. Usually, classes in teaching foreign languages are recommended to be planned and conducted according to the following principles: from general to specific, from simple to complex and from easy to difficult, etc.

As R.K. Potapova points out, "at the turn of the century, phonetics and phonology are gaining a "second wind", drawing strength from the source of ideas for new theoretical and applied problems, new speech and information technologies, new needs in the study of eternally vivid and attractive sounding speech" [1, p. 151].

Linguistic communication, being the main result of teaching a foreign language, "cannot be", notes M.T. Djusupov, "a panacea without a method of teaching a foreign language. Communicative learning gives lasting positive results when other teaching methods and techniques are used to enhance, improve communicative learning" [2, p. 78].

\section{THE MAIN FINDINGS AND RESULTS}

Phonetic interference as a result of the interaction of speech skills is one of the main 
CURRENT RESEARCH JOURNAL OF PHILOLOGICAL SCIENCES 2(10): 63-

66, October 2021

DOI: https://doi.org/10.37547/philological-crjps-02-10-13

ISSN 2767-3758

(C2021 Master Journals

Crossref do

8 Google

Accepted $26^{\text {th }}$ October, 2021 \& Published $31^{\text {th }}$ October, 2021

factors; inhibiting the formation of pronunciation skills when mastering a second foreign language. The correct choice of a set of exercises and taking into account the specifics of the native language can help overcome phonetic interference when contacting languages of different systems.

As a result of the research carried out, the following provisions have been determined:

1. In the conditions of Arabic-Uzbek bilingualism, the source of phonetic interference is the allomorphism of the phonological systems of the Arabic and Uzbek languages. According to the results of a comparative analysis, it can be argued that a specific feature of allomorphism is the difference in the inventory of phonemes and allophones.

2. As a result of this study, zones of phonetic interference were identified when teaching Arabic in the Uzbek audience.

3. The use of a set of exercises for teaching Arabic pronunciation predetermines the effectiveness of reducing the level of phonetic interference among students of Uzbek groups and thereby forms the auditory-pronunciation skills of the Arabic language.

To conduct experimental training, we carried out the following activities:

1. Phonetic material was selected on the basis of the principle of subordination to lexical material and situations of communication in accordance with the program requirements, as well as speech material to activate hearing and pronunciation skills. This material was distributed over two years of study.

2. A complex of special phonetic exercises has been developed for the formation, correction and improvement of the hearing and pronunciation skills of Arabic speech.

3. Methodological recommendations in the form of instructions for teachers on teaching have been developed. The following principles were taken into account in the development of a set of exercises to overcome phonetic interference when teaching Arabic in the Uzbek audience:

- The scientific nature of the construction of exercises and the organization of the experiment;

- Differentiation of educational material;

- The sequence and relationship of the work carried out;

- The consciousness of students who participated in the experiments.

All of these factors had a positive effect on the course of the experiments.

\section{Conclusion}

1. Phonetic interference is one of the main factors inhibiting the formation of pronunciation skills in a foreign language. As a psychological phenomenon, interference is characterized by the following features: at the level of perception, it causes difficulties in understanding the speaker's speech, and at the level of reproduction, it distorts the appearance of a speech utterance. The intensity of the interference depends on the level of formation of the pronunciation skills of the speech of Uzbek students. As a result of this study, zones of phonetic interference were identified when teaching Arabic in the Uzbek audience:

1) phonetic interference is manifested in a group of sounds that have no analogues in the Uzbek language of students, for example: / sa /, / sin /, / sad /;

2) the most frequent errors are when students do not distinguish between the sound / ain / and / hamzu /, for example: / a'mara / - / a'mara /, / a'mala / - / a'mala /, / sual / - / 
CURRENT RESEARCH JOURNAL OF PHILOLOGICAL SCIENCES 2(10): 63-

66, October 2021

DOI: https://doi.org/10.37547/philological-crjps-02-10-13

ISSN 2767-3758

(C2021 Master Journals

Crossref do) 818 Google

Accepted $26^{\text {th }}$ October, 2021 \& Published $31^{\text {th }}$ October, 2021

sua'l /;

3) phonetic interference manifests itself in the case of unification of consonants / xa /, /x..a/, / x-a /;

4) in the speech of students there is a replacement / dal / na / d.ad /;

5) many students distorted the pronunciation / za /, / zal /, /z.a /;

6) some students replaced the emphatic / t.a/ with the front-lingual / ta /;

7) in the course of observation, cases of incorrect articulation of emphatic consonants were revealed, for example: / ard / - / arz /, / marad / - / maraz /;

8) students did not distinguish well the correlates of the phonemes of the Arabic language, so there is a shift of the hard sound to the soft one, for example: / $\mathrm{m} / \mathrm{-} / \mathrm{m} \mathrm{l} / \mathrm{k}$ / - / k' /, / l / - l'/;

9) when students liken the consonants of the Arabic language to their native semi-soft ones. Basically, this phenomenon was encountered when reading borrowings, for example: /t.olib/- / t'olib /;

10) with incorrect articulation of the sounds / $\mathrm{f} /$, / w /.

11) in case of replacement by the students of the labiodental / v / labial-labial allophone / w /;

12) when students stun voiced consonants, which is unacceptable for the features of the Arabic language, for example: / ahad / - / ahat /, /s.amad / - /s.amat/.

Consequently, the results of this study give the right to believe that interference errors are made in the following cases:

a) under differentiation, i.e. indistinguishability of soft and hard consonants of the Arabic language. b) over differentiation, i.e. replacing Arabic sounds with the sounds of the Uzbek language, which have no similarity in the Arabic language.

c) in cases of sound substitution (when the Arabic sound is replaced by the equivalent sound of the Uzbek language).

2. Analysis of textbooks and teaching aids on the Arabic language showed that there is no unambiguous opinion on the issue of phonetic characteristics. This explains the focus of our research and the development of the sounds of the Arabic language in comparison with the Uzbek language, as well as because of the existing shortage of phonetic material for practical training in the method of teaching Arabic pronunciation in the Uzbek audience. In each textbook there are discrepancies in the characteristics of Arabic sounds. The result of such research is the developed and proposed by us a new author's table of phonetic classifications of sounds of the Arabic language.

3. In the conditions of Arabic-Uzbek bilingualism, the source of phonetic interference is the allomorphism of the phonological systems of the Arabic and Uzbek languages. According to the results of a comparative analysis, it can be argued that a specific feature of allomorphism is the difference in the inventory of phonemes and allophones. Based on the results of the comparative typological analysis of the Arabic and Uzbek languages, it can be concluded that consonants have several positional shades, depending on the location in the word. The most distinctive feature of the pronunciation base of the Arabic language, in comparison with Uzbek, is the fact that the tendency towards implosive pronunciation prevails in the Uzbek language and in Arabic towards explosive pronunciation;

4. A set of exercises was prepared, which proved itself in the course of experiments both in the 
CURRENT RESEARCH JOURNAL OF PHILOLOGICAL SCIENCES 2(10): 63-

66, October 2021

DOI: https://doi.org/10.37547/philological-crjps-02-10-13

ISSN 2767-3758

(C)2021 Master Journals

Crossref doi 81 Google

Accepted $26^{\text {th }}$ October, 2021 \& Published $31^{\text {th }}$ October, 2021

classroom and outside the auditorium, contributed to the improvement of the pronunciation of Arabic sounds, and also positively influenced the improvement of the educational process. The use of a set of exercises for teaching Arabic pronunciation predetermines the effectiveness of reducing the level of phonetic interference among students of Uzbek groups and thereby forms the auditory-pronunciation skills of the Arabic language. The indicators show that $58 \%$ of students from the experiment group and $41 \%$ of students in the control group were able to adequately voice the meaningful consonant phonemes. By $17 \%$ in the experiment group the students mastered the pronunciation skills better than in the control group. 58\% in the experiment group is a satisfactory indicator of the effectiveness of our proposed technology of teaching consonantisms and this is due to the systematic use of a set of special exercises that we have developed.

\section{ReFERENCES}

1. Potapova R.K. (1974) Auditory assessment of the time contour of the phrase segments. Proceedings of ARSO-8. Lvov. - Part 3. - pp. 87-89. Potapova R.K. (2003) Speech: communication, information, cybernetics. Moscow: URSS. - p. 151 (Потапова Р.K. Слуховая оценка временного контура сегментов фразы // Труды АРСО-8. Львов, 1974. - Ч. 3. - С. 87-89. Потапова Р.К. Речь: коммуникация, информация, кибернетика. М.: УРСС, 2003. - С.151)

2. Dzhusupov M. D. (2002) Linguistic, sociolinguistic and comparative typological foundations of teaching the Russian language. Philological Matters. - Tashkent. No. 1-2, - p. 78. (Джусупов М. Д. Лингвометодические, социолингвистические и сравнительно- типологические основы преподавания русского языка // Филология масалалари. - Ташкент, 2002. - № 1-2, C.78.) 